\title{
Climate-Driven Interannual Variability in Net Ecosystem Exchange in the Northern Great Plains Grasslands
}

\author{
Li Zhang, ${ }^{1}$ Bruce K. Wylie, ${ }^{2}$ Lei Ji, ${ }^{3}$ Tagir G. Gilmanov, ${ }^{4}$ and Larry L. Tieszen ${ }^{5}$
}

Authors are ${ }^{1}$ Associate Professor, Center for Earth Observation and Digital Earth, Chinese Academy of Sciences, Beijing 100101, China; Visiting Scientist, US Geological Survey (USGS) Earth Resources Observation and Science (EROS) Center, Sioux Falls, SD 57198, USA; ${ }^{2}$ Research Physical Scientist, USGS EROS Center, Sioux Falls, SD 57198, USA; ${ }^{3}$ Senior Scientist, ASRC Research and Technology Solutions, contractor to USGS EROS Center, Sioux Falls, SD 57198, USA (work performed under USGS contract 08HQCN0007); ${ }^{4}$ Professor, Department of Biology and Microbiology, South Dakota State University, Brookings, SD 57007, USA; and ${ }^{5}$ Branch Manager, USGS EROS Center, Sioux Falls, SD 57198, USA.

\begin{abstract}
The Northern Great Plains grasslands respond differently under various climatic conditions; however, there have been no detailed studies investigating the interannual variability in carbon exchange across the entire Northern Great Plains grassland ecosystem. We developed a piecewise regression model to integrate flux tower data with remotely sensed data and mapped the 8-d and 500-m net ecosystem exchange (NEE) for the years from 2000 to 2006. We studied the interannual variability of NEE, characterized the interannual NEE difference in climatically different years, and identified the drought impact on NEE. The results showed that NEE was highly variable in space and time across the 7 yr. Specifically, NEE was consistently low $(-35$ to $32 \mathrm{~g} \mathrm{C} \cdot \mathrm{m}^{-2} \cdot \mathrm{yr}^{-1}$ ) with an average annual NEE of $-2 \pm 24 \mathrm{~g} \mathrm{C} \cdot \mathrm{m}^{-2} \cdot \mathrm{yr}^{-1}$ and a cumulative flux of $-15 \mathrm{~g} \mathrm{C} \cdot \mathrm{m}^{-2}$. The Northern Great Plains grassland was a weak source for carbon during 2000-2006 because of frequent droughts, which strongly affected the carbon balance, especially in the Western High Plains and Northwestern Great Plains. Comparison of the NEE map with a drought monitor map confirmed a substantial correlation between drought and carbon dynamics. If drought severity or frequency increases in the future, the Northern Great Plains grasslands may become an even greater carbon source.
\end{abstract}

\section{Resumen}

Los pastizales de las grandes planicies del norte responden de manera diferente bajo diversas condiciones climáticas; sin embargo, no ha habido ningún estudio en detalle que investigue la variabilidad entre años en el intercambio de carbono a través de todo el ecosistema de los pastizales de las grandes planicies del norte. Desarrollamos un modelo de regresión para integrar los datos de la torre de flujo con datos medidos de forma remota y establecer el intercambio de ecosistema neto (NEE) de 8 días y 500-m durante los años del 2000 al 2006. Estudiamos la variabilidad de NEE entre años caracterizando las diferencias climáticas entre años, e identificando el impacto de sequía en NEE. Los resultados mostraron que NEE fue demasiado variable en espacio y tiempo a través de los 7 años. Específicamente, NEE fue constantemente bajo $\left(-35\right.$ to $\left.32 \mathrm{~g} \mathrm{C} \cdot \mathrm{m}^{-2} \cdot \mathrm{yr}^{-1}\right)$ con un promedio anual NEE de $-2 \pm 24 \mathrm{~g} \mathrm{C} \cdot \mathrm{m}^{-2} \cdot \mathrm{yr}^{-1}$ y una variación acumulada de $-15 \mathrm{~g} \mathrm{C} \cdot \mathrm{m}^{-2}$. Los pastizales de las planicies del norte fueron una fuente baja de carbono durante los años 2000-2006 debido a las sequías frecuentes, que afectan considerablemente el equilibrio de carbono, especialmente en la parte occidental de las altas planicies y en el noroeste de las grandes planicies. Comparación del registro de NEE con un mapa de monitoreo de la sequía confirmó una sustancial correlación entre la sequía y la dinámica del carbono. Si la gravedad o frecuencia de la sequía es aumenta en el futuro, los pastizales de las grandes planicies del norte pueden convertirse en una fuente de carbono aún mayor.

Key Words: drought, flux tower, Moderate Resolution Imaging Spectroradiometer (MODIS), normalized difference vegetation index (NDVI), piecewise regression tree

\section{INTRODUCTION}

Grasslands constitute approximately $40 \%$ of the Earth's terrestrial land area, excluding areas of permanent ice cover

Research was funded by the USGS Earth Surface Dynamics, Land Remote Sensing, and Geographic Analysis and Monitoring Programs.

Any use of trade, product, or firm names is for description purposes only and does not imply endorsement by the US Government.

This publication was made possible through support provided to the Global Livestock Collaborative Research Support Program by the Office of Agriculture, Bureau for Economic Growth, Agriculture and Trade, United States Agency for International Development under terms of Grant No. PCE-G-00-98-00036-00. The opinions expressed herein are those of the author(s) and do not necessarily reflect the views of the USAID.

Correspondence: Li Zhang, Center for Earth Observation and Digital Earth, Chinese Academy of Sciences, PO Box 9718, 20A Datun Rd, Chaoyang District, Beijing 100101, China. Email: lizhang@ceode.ac.cn

Manuscript received 18 November 2008; manuscript accepted 21 October 2009
(World Resources Institute 2000). The grasslands in the US Great Plains, occupying about 1.5 million $\mathrm{km}^{2}$, are characterized by different photosynthetic pathways that change from $\mathrm{C}_{3}$ dominance in the north to $\mathrm{C}_{4}$ dominance in the south (Tieszen et al. 1997). These grasslands serve as resources for livestock production in North America and are important contributors to climate regulation and global carbon balance. Previous studies have suggested that grassland ecosystems may function as potential carbon sinks, or are near equilibrium, and could contribute to balancing the global carbon budget in the tallgrass prairie (Dugas et al. 1999), mixed-grass prairie (Frank and Dugas 2001; Sims and Bradford 2001; Frank 2004; Haferkamp and MacNeil 2004), sagebrush steppe (Gilmanov et al. 2006), and other temperate grassland ecosystems (Janssens et al. 2003; Piao et al. 2007). However, grassland ecosystems also release carbon into the atmosphere during 
drought (Kim et al. 1992; Granier et al. 2007; Pereira et al. 2007; Arnone et al. 2008). Droughts usually limit grass growth and are the main cause of interannual variation in terrestrial carbon sequestration because they cause large reductions in both gross primary production (GPP) and net ecosystem exchange (NEE). Researchers reported that grassland ecosystems shifted from a carbon sink in a nondrought year to a carbon source in a drought year in the Southern Great Plains (Meyers 2001), a semiarid sandy grassland in the Great Hungarian Plain (Nagy et al. 2007), a European grassland (Gilmanov et al. 2007), and a Mediterranean grassland (Aires et al. 2008).

During the 20th century, annual average temperatures in the Northern Great Plains have risen more than $1^{\circ} \mathrm{C}$ and nearly $3{ }^{\circ} \mathrm{C}$ in portions of Montana, North Dakota, and South Dakota (Joyce et al. 2001). Temperatures are predicted to continue to rise throughout the region, with the largest increases in the northern and western parts of the Great Plains (Joyce et al. 2001). The desiccating effect of higher temperatures is expected to more than offset the benefit of higher precipitation, resulting in lower soil water content and increased drought throughout most of the Great Plains (Morgan et al. 2008). During the past 100 years, annual precipitation has decreased by $10 \%$ in eastern Montana, North Dakota, eastern Wyoming, and Colorado (Joyce et al. 2001). Severe droughts experienced throughout the Great Plains in 2002 and 2006 (National Climatic Data Center [NCDC] 2009) support the prediction of increased drought.

Understanding carbon sink or source behaviors in the Northern Great Plains grasslands under various climatic conditions, especially drought, requires knowledge of interannual variation in ecosystem carbon exchange with the atmosphere. So far, at least six flux towers have been operational in grasslands of the Northern Great Plains. Although these towers acquire useful flux information about grassland ecosystems, the contributions of grasslands to local and regional carbon budgets and their sensitivity to climatic perturbations (e.g., drought) remain uncertain because of the limited number of long-term measurement sites for these expansive grassland ecosystems. Most of the existing estimates of interannual variation of NEE in the Northern Great Plains grasslands were investigated at specific sites based on the eddycovariance and Bowen Ratio Energy Balance (BREB) measurements (Frank and Dugas 2001; Flanagan et al. 2002; Frank 2004; Gilmanov et al. 2005; Heitschmidt et al. 2005; Svejcar et al. 2008). At the regional scale, Phillips and Beeri (2008) recently investigated growing season NEE in North Dakota grasslands under the Conservation Reserve Program where NEE showed a high regional and temporal variability. However, there have been no detailed long-term estimates of $\mathrm{CO}_{2}$ exchange or studies investigating the interannual variability across the entire Northern Great Plains.

Global satellite data sets, based on the relationships between grassland $\mathrm{CO}_{2}$ and spectral vegetation indices (Wylie et al. 2004; Gilmanov et al. 2005), have provided opportunities for regional monitoring of temporal variation of terrestrial ecosystems. By combining flux tower data and remotely sensed environmental variables, diverse empirical models have been developed for estimating GPP or NEE at regional and continental scales through the use of the support vector machine approach (Yang et al. 2007), piecewise regression tree (Wylie et al. 2007; Zhang et al. 2007; Xiao et al. 2008), stepwise linear regression (Phillips and
Beeri 2008), and physiologically based models (Oechel et al. 2000; Turner et al. 2003; Hassan et al. 2006). To address the absence of the detailed analysis of the long-term carbon budget in the Northern Great Plains under different climatic conditions, we developed a remote sensing-based empirical model, the rule-based piecewise regression (PWR) model. We recently enhanced our PWR model by improving input data sets from the earlier model (Wylie et al. 2007; Zhang et al. 2007). The improvements include 1) use of Moderate Resolution Imaging Spectroradiometer (MODIS) data with higher temporal (8-d), spatial (500-m), and spectral resolutions (seven-band), 2) incorporation of actual vegetation evapotranspiration data that takes into account soil moisture and land surface phenology, and 3) addition of another flux tower at Brookings, South Dakota, and additional years at other existing flux towers for model development and assessment.

In this study, we applied the PWR model to all pixels in the satellite images to map NEE at 8 -d intervals and 500-m spatial resolution for 2000-2006 in the Northern Great Plains grasslands. Our primary objectives in this study were to 1) quantify the interannual variability of NEE and characterize interannual differences in NEE in climatically different years, 2) identify the carbon sink and source areas in spatial and temporal space, and 3) identify the drought impact on grassland ecosystems. Our research hypothesis was that the Northern Great Plains grassland ecosystem will respond differently under various climatic conditions and that drought will strongly affect the carbon balance in these grasslands. In our study, we used the ecological sign convention (opposite of atmospheric science) to show efflux of $\mathrm{CO}_{2}$ as negative and uptake of $\mathrm{CO}_{2}$ from the atmosphere as positive.

\section{MATERIALS AND METHODS}

\section{Study Area and Flux Tower}

We conducted this study in the Northern Great Plains (lat $39^{\circ} 00^{\prime}-49^{\circ} 00^{\prime} \mathrm{N}$, long $95^{\circ} 00^{\prime}-115^{\circ} 00^{\prime} \mathrm{W}$ ), which crosses parts of six states including North Dakota, South Dakota, Montana, Wyoming, Nebraska, and Colorado (Fig. 1). The Northern Great Plains encompass the Northern Glaciated Plains, Northwestern Glaciated Plains, Northwestern Great Plains, Western High Plains, and Montana Valley and Foothill Prairies as defined by Omernik's level III ecoregions (Omernik 1987). We used the 2001 National Land Cover Database (NLCD) (Homer et al. 2004) to identify grassland areas, which include two NLCD land cover classes: grassland and pasture.

The climate in the Northern Great Plains follows a northsouth temperature gradient and an east-west precipitation gradient. Based on 30-yr (1961-1999) normals (High Plains Regional Climate Center, http://www.hprcc.unl.edu), the mean annual precipitation in this region varies from $380 \mathrm{~mm}$ in the west to $760 \mathrm{~mm}$ in the east. Precipitation occurs primarily during the summer months. The mean annual temperature ranges from $4^{\circ} \mathrm{C}$ in the north to $11^{\circ} \mathrm{C}$ in the south. Grassland constitutes the major land cover $(49.7 \%)$ in the Northern Great Plains (NLCD 2001 data; Homer et al. 2004), with the $\mathrm{C}_{3}$ grassland dominant in the north and $\mathrm{C}_{4}$ species prevalent in the south. The grasses transition from western wheatgrass (Pascopyrum smithii), porcupinegrass (Hesperostipa spartea [Trin.] Barkworth), grama grass (Bouteloua sp.), and buffalo grass (Boutelona dactyloides 


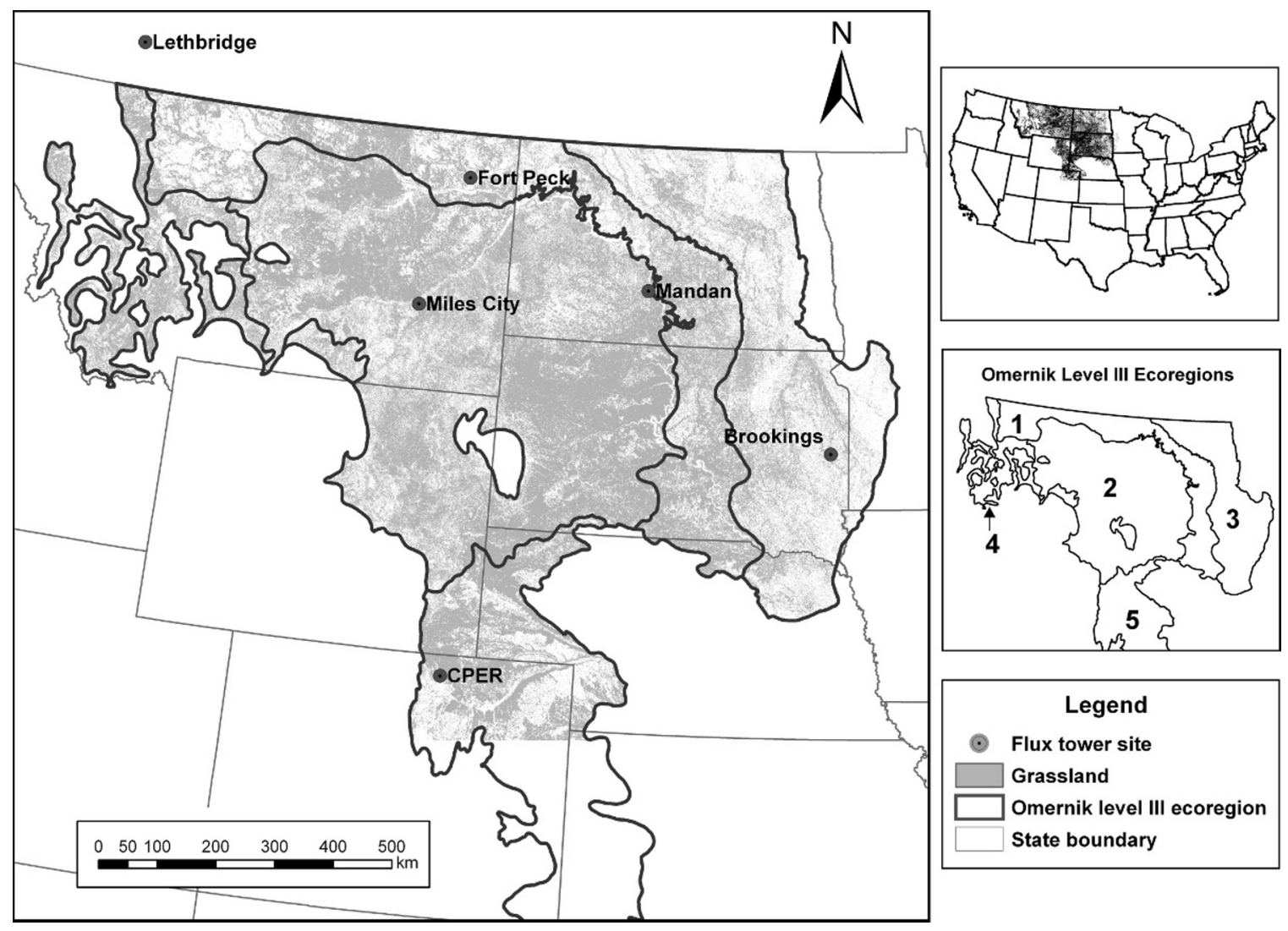

Figure 1. Study area and grassland flux towers in the Northern Great Plains. In the Omernik Level III Ecoregions map on the right-central panel, the number represents: 1 Northwestern Glaciated Plains, 2 Northwestern Great Plains, 3 Northern Glaciated Plains, 4 Montana Valley and Foothill Prairies, and 5 Western High Plains.

[Nutt.] J.T. Columbus) in the north to grama and buffalo grasses in the south, and from wheatgrass, bluestem (Andropogon gerardii Vitman), needlegrass, and Indiangrass (Sorghastrum nutans [L.] Nash) in the east to the subhumid grassland and semiarid grazing land in the west (Omernik 1987).

Grassland NEE was measured at six flux towers that are evenly distributed throughout the Northern Great Plains (Fig. 1). These sites represent wide spatial, ecological, and climatological ranges of grasslands across this region. The gapfilled NEE data for these sites (originally from AmeriFlux and AgriFlux networks) were taken from the WorldGrassAgriflux data sets (Gilmanov et al. 2010). The three AmeriFlux towers (Lethbridge, Canada; Fort Peck, Montana; Brookings, South Dakota) use the eddy covariance technique, and the other three AgriFlux towers (Mandan, North Dakota; Miles City, Montana; Central Plains Experimental Range, Colorado) use the BREB technique (Table 1). Both the eddy covariance and BREB methods have been shown to provide accurate and consistent measurements of carbon fluxes in the short-statured plant communities of the Northern Great Plains (Gilmanov et al. 2005 ) and the Southern Plains (Gilmanov et al. 2003). In this study, we used tower-measured NEE as the training data set for the PWR model and the testing data set for model validation.

\section{Model Method}

In this study, we used the rule-based piecewise regression model (Wylie et al. 2007; Zhang et al. 2007) to estimate the grassland carbon fluxes above the Northern Great Plains. The PWR model integrates spatial data sets and flux data from six grassland towers to estimate the spatiotemporal carbon fluxes across the study area by exploring the empirical relationship among environmental variables and tower measurements. The PWR model was developed using Cubist software (http://www. rulequest.com; Quinlan 1993), in which training samples are recursively partitioned into homogeneous subsets according to a gain ratio criterion. The subsets are expressed as a series of rules where each rule defines the conditions under which a multivariate linear regression model is established based on a variant of least-squares estimation. In Cubist, the accuracy of the constructed piecewise regression tree is measured with average error, relative error, and product-moment correlation coefficient, which were also used to select the most relevant predictive variables. These piecewise rules are adaptive, allowing NEE to be estimated for any given 8-d period for any rangeland pixel within the ecoregion (Wylie et al. 2007). The final regression tree model was based on the most relevant predictive variables and all available training data and then applied through time and space to estimate the 8-d and 500-m NEE.

In this study, the PWR model required two types of data sets as input: 1) flux tower data for model training and validation and 2) explanatory or predictive remotely sensed and climatic data sets. The regression tree method was used to identify the most important variables for estimating NEE maps. A preliminary analysis of the frequency of use and relevance in 
Table 1. Description of the grassland flux towers in the Northern Great Plains.

\begin{tabular}{|c|c|c|c|c|c|}
\hline Site & Year & Ecosystem & Latitude, longitude & Elevation (m) & Principal investigator \\
\hline Lethbridge & 2000-2001 & Northern mixed-short grass prairie & $49^{\circ} 42^{\prime} \mathrm{N}, 112^{\circ} 56^{\prime} \mathrm{W}$ & 960 & Flanagan, L. B. \\
\hline Fort Peck & 2000,2002 & Northern mixed prairie & $48^{\circ} 18^{\prime} \mathrm{N}, 105^{\circ} 06^{\prime} \mathrm{W}$ & 634 & Meyers, T. P. \\
\hline Mandan & $2000-2002$ & Mixed prairie & $46^{\circ} 46^{\prime} \mathrm{N}, 100^{\circ} 55^{\prime} \mathrm{W}$ & 518 & Frank, A. B. \\
\hline Miles City & $2000-2001$ & Northern mixed prairie & $46^{\circ} 18^{\prime} \mathrm{N}, 105^{\circ} 58^{\prime} \mathrm{W}$ & 719 & Haferkamp, M. R. \\
\hline Brookings & 2006 & Tallgrass prairie & $44^{\circ} 19^{\prime} \mathrm{N}, 96^{\circ} 48^{\prime} \mathrm{W}$ & 510 & Meyers, T. P. \\
\hline Central Plains Experimental Range & $2000-2001$ & Shortgrass steppe & $40^{\circ} 41^{\prime} \mathrm{N}, 104^{\circ} 45^{\prime} \mathrm{W}$ & 1660 & Morgan, J. A. \\
\hline
\end{tabular}

the regression models revealed the most important predictive variable for the final PWR model. The remotely sensed predictors included the 8-d composite and 500-m MODIS normalized difference vegetation index (NDVI), normalized difference water index (NDWI), and phenological metrics. The phenological metrics were calculated from a time series of annual smoothed MODIS NDVI data on a per-pixel basis for each year from 2000 to 2006, using the delayed moving average method (Reed et al. 1994; Reed 2006). The phenological metrics chosen in the PWR model included day of year (DOY), day of maximum NDVI (MAXT), day of the start of the growing season (SOST), and seasonally time-integrated NDVI (TIN). The climatic variables included precipitation (PPT) data, temperature data, photosynthetically active radiation (PAR), and actual vegetation evapotranspiration. The long-term climatic precipitation and temperature data were acquired from the National Oceanic and Atmospheric Administration (NOAA) Climate Prediction Center, and PAR data were obtained from the NOAA National Environmental Satellite, Data and Information Service (NESDIS; http://www. atmos.umd.edu/ $\sim$ srb/gcip). The actual vegetation evapotranspiration data were derived from a VegET model (Senay 2008) that integrated the commonly used water balance algorithm with the remotely sensed land surface phenology parameter to estimate landscape actual evapotranspiration. For the regional application, all spatial inputs were resampled to $500-\mathrm{m}$ resolution raster data.

We took the 10 selected variables (most relevant predictors) to train the final PWR model. The final model estimated NEE reasonably well with $r=0.84$. The PWR model consisted of five rules, each of which was made of a regression function. For example, one of the rules is listed here:

$$
\begin{aligned}
& \text { Rule 1: if DOY } \leq 177, \text { SOST } \leq 118, \text { MAXT } \leq 183 \text {, } \\
& \mathrm{NEE}=-606.6+4.1 \mathrm{INDVI}-0.85 \mathrm{DOY}+1.8 \mathrm{PAR} \\
& -3.38 \mathrm{TIN}+1.2 \mathrm{SOST}-0.31 \mathrm{PPT}+0.04 \mathrm{MAXT} \\
& -0.16 \mathrm{NDWI}
\end{aligned}
$$

\section{Model Assessment}

Leave-one-out cross validation (LOOCV) was applied to evaluate the PWR model and NEE map accuracy, which is an effective method to compensate for the effect of a limited number of training sites. In LOOCV, one data subset (one site or one year) is withheld as a test sample for assessing the model and map accuracies, and the remaining samples are used as training samples for the model development. Each site (or year) was successively withheld as the test samples, and NEE was then estimated for the withheld site (or year) from the model developed with the remaining sites (or years). For the sitewithheld LOOCV, the actual NEE value measured at each flux tower site was compared to the model-estimated NEE value using the training data set of all other sites. Similarly, for the year-withheld LOOCV, the actual NEE value measured for a year was compared to the model-estimated NEE value using the training data set of all other years. By comparing the measured and estimated samples, the Pearson's correlation coefficient $(r)$ and root mean square error (RMSE) were used to quantify the model and map accuracies. At the Lethbridge site, estimates from the PWR model were unavailable because of a lack of meteorological data in Canada. The tower-measured NEE and climate data at the Lethbridge tower were used as the training data for developing the PWR model.

\section{RESULTS AND DISCUSSION}

\section{Model Accuracy Assessment}

We compared the PWR-estimated NEE with the towermeasured NEE using LOOCV by withholding each site and each year (Figs. 2 and 3). The performance of the PWR models varied depending on which flux tower site or which measurement year was withheld. The high model accuracy is represented by the scatter plots that have estimates closer to the 1:1 line, high correlations between tower-measured and PWR-estimated NEE, and low RMSE (Figs. 2 and 3; Table 2). The regressions of tower-measured and PWR-estimated NEE in the LOOCV indicated $r=0.75-0.91$ and RMSE $=0.29$ $-0.59 \mathrm{~g} \mathrm{C} \cdot \mathrm{m}^{-2} \cdot \mathrm{d}^{-1}$ for NEE estimation by withholding sites, and $r=0.76-0.84$ and $\mathrm{RMSE}=0.38-0.46 \mathrm{~g} \mathrm{C}$. $\mathrm{m}^{-2} \cdot \mathrm{d}^{-1}$ for withholding years. The means and standard deviation (SD) values for each pair of the tower-measured and PWR NEE are close (as represented by the low differences of means and SD), which indicates high precision of the PWR model estimation (Table 2).

The accuracy of NEE estimations was relatively low when withholding the Mandan and Miles City sites compared to other sites $(r=0.77$ at Mandan and $r=0.75$ at Miles City), which implies that the Mandan and Miles City sites were influential sites for training the PWR model. The Mandan site represents a wet site because the total precipitation at the Mandan site for the 2000 and 2001 growing seasons was $458 \mathrm{~mm}$ and $429 \mathrm{~mm}$, respectively, which is generally higher 

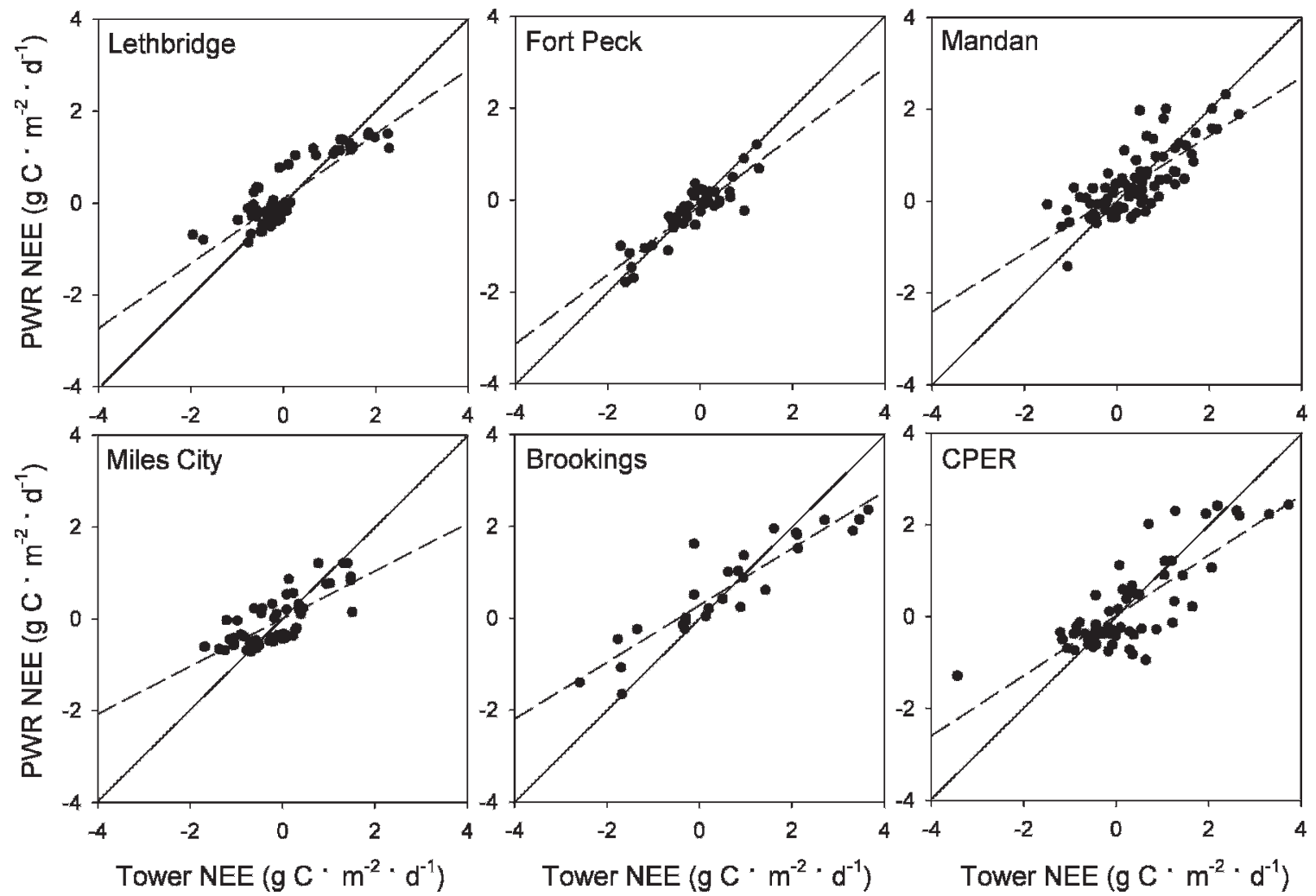

Figure 2. Comparison of tower-measured and piecewise regression (PWR)-estimated net ecosystem exchange (NEE) through cross validation by withholding each site. Graphs are labeled with the name of the withheld site. The dashed line represents the regression line. The solid line represents the $1: 1$ line.

than other sites or years. The Miles City site in 2000 and the Mandan site in 2002 represent dry sites. When withholding the years 2000 and 2002, the accuracy of NEE estimations was relatively low with $r=0.76$ for both years, which implies that the two years were influential for the PWR model. The year 2000 represented a wet year and 2002 a dry year in the training data sets. In general, the PWR model performed well when it was developed based on adequate samples of flux tower sites and years, which represent a broad extent of geographic characteristics, climatic variability, and plant biophysical features (e.g., different photosynthetic pathways $\left.\left[\mathrm{C}_{3} / \mathrm{C}_{4}\right]\right)$. By including the data sets of all the sites and all the years from the six flux towers, the final model robustness was maximized for a wide range of geographic, climatic, and ecological conditions. After assessing model performance with the LOOCV method, we trained the final model using the complete flux tower data sets. The final PWR model accuracy for NEE estimates was reasonably high with $r=0.84$.

Issues regarding model accuracy need to be addressed. First, an ideal NEE estimation based on the flux towers should not be extrapolated beyond a reasonable range from the training data set. In this study, the series of PWR model equations constrained their predictions to not exceed $10 \%$ beyond the training range. Second, the winter flux estimation was probably the weakest component of our PWR model because some of the flux tower data sets did not span the entire winter period and
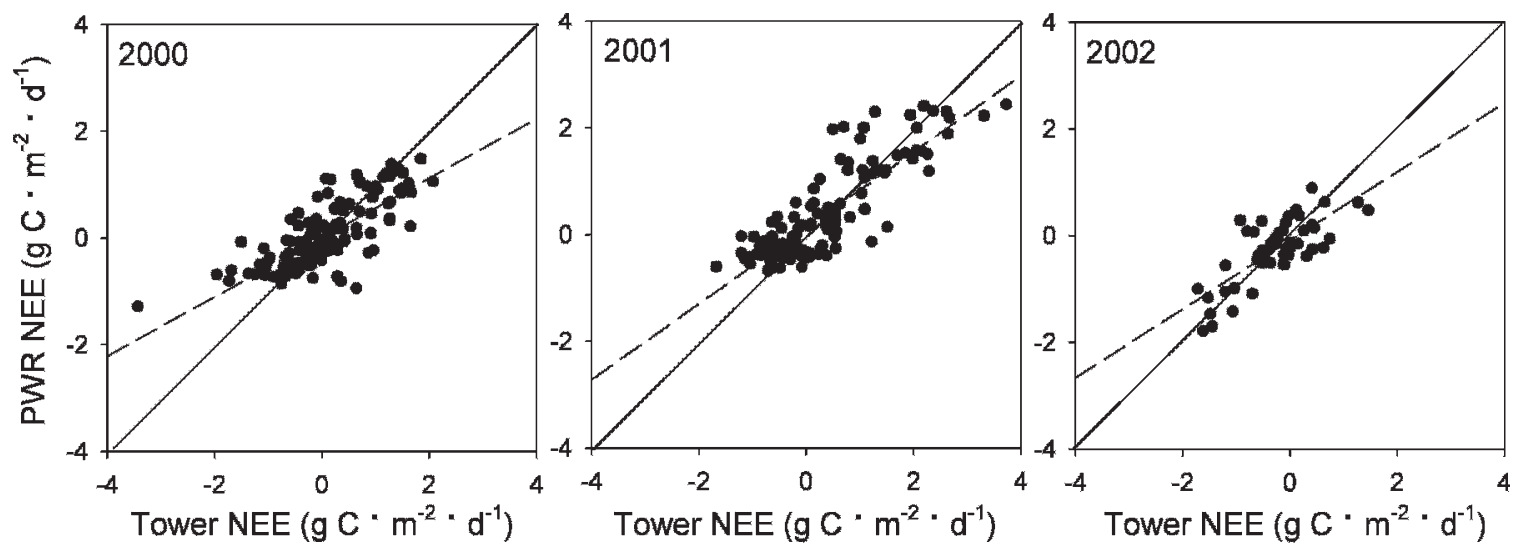

Figure 3. Comparison of tower-measured and piecewise regression (PWR)-estimated net ecosystem exchange (NEE) through cross validation by withholding each year. Graphs are labeled with the name of the withheld year. The dashed line represents the regression line. The solid line represents the 1:1 line. 
Table 2. Leave-one-out cross validation of piecewise regression (PWR)-estimated net ecosystem exchange (NEE) by withholding each site or each year. ${ }^{1}$

\begin{tabular}{|c|c|c|c|c|c|c|c|c|c|c|}
\hline \multirow[b]{2}{*}{ Parameter } & \multicolumn{6}{|c|}{ Withholding site } & \multicolumn{4}{|c|}{ Withholding year } \\
\hline & Lethbridge & $\begin{array}{l}\text { Fort } \\
\text { Peck }\end{array}$ & Mandan & $\begin{array}{l}\text { Miles } \\
\text { City }\end{array}$ & Brookings & CPER $^{2}$ & 2000 & 2001 & 2002 & 2006 \\
\hline$n$ (no. of observations) & 70 & 45 & 84 & 58 & 28 & 61 & 136 & 129 & 53 & 28 \\
\hline Mean of tower NEE $\left(\bar{T}_{\text {nee }} ; \mathrm{g} \mathrm{C} \cdot \mathrm{m}^{-2} \cdot \mathrm{d}^{-1}\right)$ & 0.03 & -0.19 & 0.37 & -0.15 & 0.61 & 0.27 & 0.06 & 0.31 & -0.29 & 0.61 \\
\hline SD of tower NEE $\left(\mathrm{g} \mathrm{C} \cdot \mathrm{m}^{-2} \cdot \mathrm{d}^{-1}\right)$ & 0.86 & 0.73 & 0.86 & 0.78 & 1.65 & 1.20 & 0.85 & 1.02 & 0.69 & 1.65 \\
\hline Mean of PWR NEE $\left(\bar{P}_{\text {nee }} ; \mathrm{g} \mathrm{C} \cdot \mathrm{m}^{-2} \cdot \mathrm{d}^{-1}\right)$ & 0.12 & -0.26 & 0.38 & -0.08 & 0.66 & 0.20 & 0.04 & 0.35 & -0.27 & 0.66 \\
\hline 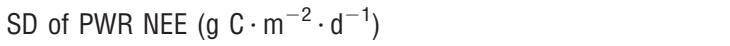 & 0.69 & 0.62 & 0.71 & 0.54 & 1.12 & 0.98 & 0.62 & 0.86 & 0.58 & 1.12 \\
\hline $\begin{array}{l}\text { Difference of mean between PWR and tower NEE }\left(\overline{P_{n e e}}-\overline{T_{n e e}}\right) \\
\left(\mathrm{g} \mathrm{C} \cdot \mathrm{m}^{-2} \cdot \mathrm{d}^{-1}\right)\end{array}$ & 0.08 & -0.07 & 0.01 & 0.07 & 0.05 & -0.07 & -0.02 & 0.04 & 0.02 & 0.05 \\
\hline Difference of SD between PWR and tower NEE $\left(\mathrm{g} \mathrm{C} \cdot \mathrm{m}^{-2} \cdot \mathrm{d}^{-1}\right)$ & -0.17 & -0.11 & -0.15 & -0.24 & -0.53 & -0.22 & -0.23 & -0.16 & -0.11 & -0.53 \\
\hline$r$ & 0.88 & 0.89 & 0.77 & 0.75 & 0.91 & 0.80 & 0.76 & 0.84 & 0.76 & 0.91 \\
\hline Root mean square error $\left(\mathrm{g} \mathrm{C} \cdot \mathrm{m}^{-2} \cdot \mathrm{d}^{-1}\right)$ & 0.34 & 0.29 & 0.46 & 0.36 & 0.46 & 0.59 & 0.40 & 0.46 & 0.38 & 0.46 \\
\hline
\end{tabular}

${ }^{1}$ The statistics for withholding the Brookings site and withholding the year 2006 are the same because Brookings is the only site with flux data for 2006.

${ }^{2}$ Central Plains Experimental Range.

captured only early spring and late winter dormant periods. Third, flux towers have errors in estimating NEE, which causes uncertainties in the NEE estimation. However, we expect the errors to be lower in flatter and windier grassland sites in the Northern Great Plains compared to other ecosystems (e.g., forested ecosystems [Baldocchi 2003]). Grassland flux towers had a negligible carbon storage term and had consistent winds that ensured relatively stable flux measurement. In addition, the flux data used in this study were carefully screened to remove erroneous outliers and fill data gaps (Gilmanov et al. 2003).

\section{Interannual NEE Variability (2000-2006)}

According to our 2000-2006 NEE maps for the Northern Great Plains grasslands, annual NEE varied from $-35 \mathrm{~g} \mathrm{C} \cdot \mathrm{m}^{-2} \cdot \mathrm{yr}^{-1}$ (source) in 2006 to $32 \mathrm{~g} \mathrm{C} \cdot \mathrm{m}^{-2} \cdot \mathrm{yr}^{-1}$ (sink) in 2001; the drier years (2002, 2004, and 2006) were sources, and the other years were sinks (Table 3). The large interannual NEE variation for the Northern Great Plains grasslands is similar to that from other grassland ecosystems. For example, large variability was reported for 20 European grasslands with NEE varying from -164 to $654 \mathrm{~g} \mathrm{C} \cdot \mathrm{m}^{-2} \cdot \mathrm{yr}^{-1}$ (Gilmanov et al.2007); these grasslands were carbon sinks during years with favorable precipitation and carbon sources in drought

Table 3. Annual net ecosystem exchange (NEE) and total precipitation (April-June) for the Northern Great Plains grasslands.

\begin{tabular}{|c|c|c|}
\hline & NEE & $\begin{array}{c}\text { Total precipitation } \\
\text { (April-June) }\end{array}$ \\
\hline Year & $\mathrm{g} \mathrm{C} \cdot \mathrm{m}^{-2} \cdot \mathrm{yr}^{-1}$ & $\mathrm{~mm}$ \\
\hline 2000 & 11 & 179 \\
\hline 2001 & 32 & 198 \\
\hline 2002 & -27 & 129 \\
\hline 2003 & 14 & 190 \\
\hline 2004 & -13 & 154 \\
\hline 2005 & 4 & 257 \\
\hline 2006 & -35 & 150 \\
\hline Mean $\pm S D$ & $-2 \pm 24$ & $180 \pm 42$ \\
\hline
\end{tabular}

years. Similar variability was also reported for a pasture in the Southern Great Plains $\left(-155\right.$ to $118 \mathrm{~g} \mathrm{C} \cdot \mathrm{m}^{-2} \cdot \mathrm{yr}^{-1}$; Meyers 2001), Canadian temperate mixed prairie $(-18$ to $21 \mathrm{~g} \mathrm{C} \cdot \mathrm{m}^{-2} \cdot \mathrm{yr}^{-1}$; Flanagan et al. 2002), Mediterranean grasslands in California $\left(-155\right.$ to $-56 \mathrm{~g} \mathrm{C} \cdot \mathrm{m}^{-2} \cdot \mathrm{yr}^{-1}$; Ma et al. 2007), semiarid grasslands in Hungary $(-80$ to $188 \mathrm{~g} \mathrm{C}$. $\mathrm{m}^{-2} \cdot \mathrm{yr}^{-1}$; Nagy et al. 2007), and grazed Mediterranean grasslands in southern Portugal $\left(-49\right.$ to $190 \mathrm{~g} \mathrm{C} \cdot \mathrm{m}^{-2} \cdot \mathrm{yr}^{-1}$; Aires et al. 2008). In the Northern Great Plains grasslands, the area of carbon sinks ranging from 0 to $150 \mathrm{~g} \mathrm{C} \cdot \mathrm{m}^{-2} \cdot \mathrm{yr}^{-1}$ were noticeably larger in 2000, 2001, 2003, and 2005 than in 2002 and 2006 (Fig. 4). Most of the areas in 2001 were carbon sinks with about $76 \mathrm{~g} \mathrm{C} \cdot \mathrm{m}^{-2} \cdot \mathrm{yr}^{-1}$. At the other extreme, most of the areas in 2002 were carbon sources with about $-10 \mathrm{~g} \mathrm{C} \cdot \mathrm{m}^{-2} \cdot \mathrm{yr}^{-1}$.

In recent studies, values of cumulative NEE during the measurement years indicated that a Southern Plains mixedgrass prairie (Sims and Bradford 2001), the central Mongolian steppe (Li et al. 2005), and Mediterranean grasslands (Aires et al. 2008) were sinks for atmospheric $\mathrm{CO}_{2}$. However, other studies conducted at a tallgrass native prairie in Texas (Dugas et al. 1999), nongrazed mixed-grass prairie in North Dakota (Frank and Dugas 2001), and $\mathrm{C}_{4}$-dominated tallgrass in Oklahoma (Suyker et al. 2003) indicated that these sites were near equilibrium for carbon. Although the previously mentioned studies suggested that grasslands may be carbon sinks or near equilibrium, alternations between carbon sink and source were not unusual, especially with extreme weather (e.g., drought; Ciais et al. 2005; Gilmanov et al. 2007). During our study period, the average annual NEE was $-2 \pm 24 \mathrm{~g} \mathrm{C} \cdot \mathrm{m}^{-2} \cdot \mathrm{yr}^{-1}$, and the cumulative flux during the $7 \mathrm{yr}$ was $-15 \mathrm{~g} \mathrm{C} \cdot \mathrm{m}^{-2}$. The Northern Great Plains grassland was a weak source for carbon during 2000-2006 because of a high frequency of drought.

Figure 5 illustrates the spatial distribution of annual NEE above the Northern Great Plains grasslands and shows the strong influence of precipitation on NEE. Considerable spatial heterogeneity was observed with extensive carbon sources in the western regions and carbon sinks in the eastern regions, generally following a west-east precipitation gradient across this region. Spatial patterns in annual NEE maps confirmed 


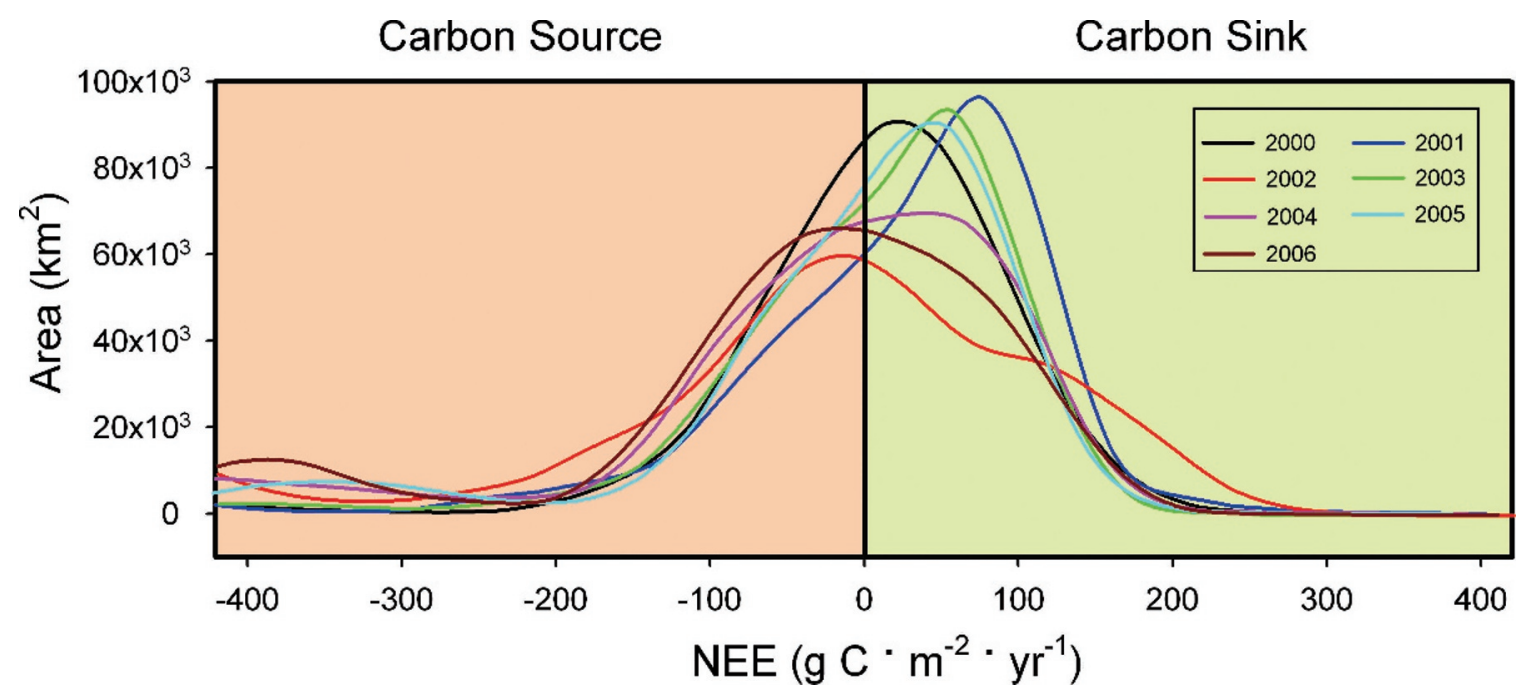

Figure 4. Areal distribution of annual net ecosystem exchange (NEE) in the Northern Great Plains grasslands during $2000-2006$.

that 2002, 2004, and 2006 were different from other years with relatively large and extensive carbon sources. Temporally, grassland ecosystems in this region were carbon sinks from April to the end of June and then changed to carbon sources after early July, shortly after the summer solstice. The monthly NEE had different spatial distributions for the normal year (2001) and the dry year (2002). In July and August 2001, NEE was dominated by negative values (sources) in the west but positive values (sinks) in the east. However, extensive sources were observed throughout the Northern Great Plains in July and August 2002.

\section{Carbon Sink and Source by Ecoregion}

Within the Northern Great Plains, individual ecoregions differed in NEE (Fig. 6). The Northern Glaciated Plains and Northwestern Glaciated Plains were always strong carbon sinks, but the Northwestern Great Plains, Western High Plains, and Montana Valley and Foothill Prairies each had a net carbon release for the 7 -yr period. The Northern Glaciated
Plains were the largest carbon sink with an average of $39 \mathrm{~g} \mathrm{C} \cdot \mathrm{m}^{-2} \cdot \mathrm{yr}^{-1}$, varying from $35 \mathrm{~g} \mathrm{C} \cdot \mathrm{m}^{-2} \cdot \mathrm{yr}^{-1}$ in 2006 to $44 \mathrm{~g} \mathrm{C} \cdot \mathrm{m}^{-2} \cdot \mathrm{yr}^{-1}$ in 2002 . The Northwestern Great Plains showed the largest carbon source with an average annual NEE of $-32 \mathrm{~g} \mathrm{C} \cdot \mathrm{m}^{-2} \cdot \mathrm{yr}^{-1}$, varying from $-79 \mathrm{~g} \mathrm{C} \cdot \mathrm{m}^{-2} \cdot \mathrm{yr}^{-1}$ in 2006 to $17 \mathrm{~g} \mathrm{C} \cdot \mathrm{m}^{-2} \cdot \mathrm{yr}^{-1}$ in 2001.

The Northwestern Great Plains had the lowest mean growing season precipitation of $266 \mathrm{~mm}$ during the 7-yr period compared to more than $300 \mathrm{~mm}$ in other ecoregions of the Northern Great Plains. A large standard deviation in annual NEE was observed over the Northwestern Great Plains during the $7 \mathrm{yr}$, especially in the northern and eastern portion of this ecoregion (Fig. 7). Precipitation decreased by $10 \%, 13 \%$, and $13 \%$ in the Northwestern Great Plains for the dry years 2002, 2004, and 2006, respectively, which resulted in considerable carbon loss $\left(-65,-56\right.$, and $-79 \mathrm{~g} \mathrm{C} \cdot \mathrm{m}^{-2} \cdot \mathrm{yr}^{-1}$, respectively). The Northwestern Great Plains released a relatively small amount of carbon $\left(-8,-7\right.$, and $\left.-23 \mathrm{~g} \mathrm{C} \cdot \mathrm{m}^{-2} \cdot \mathrm{yr}^{-1}\right)$ in 2000,2003 , and 2005 and was a carbon $\operatorname{sink}\left(18 \mathrm{~g} \mathrm{C} \cdot \mathrm{m}^{-2} \cdot \mathrm{yr}^{-1}\right)$ in the normal year, 2001.

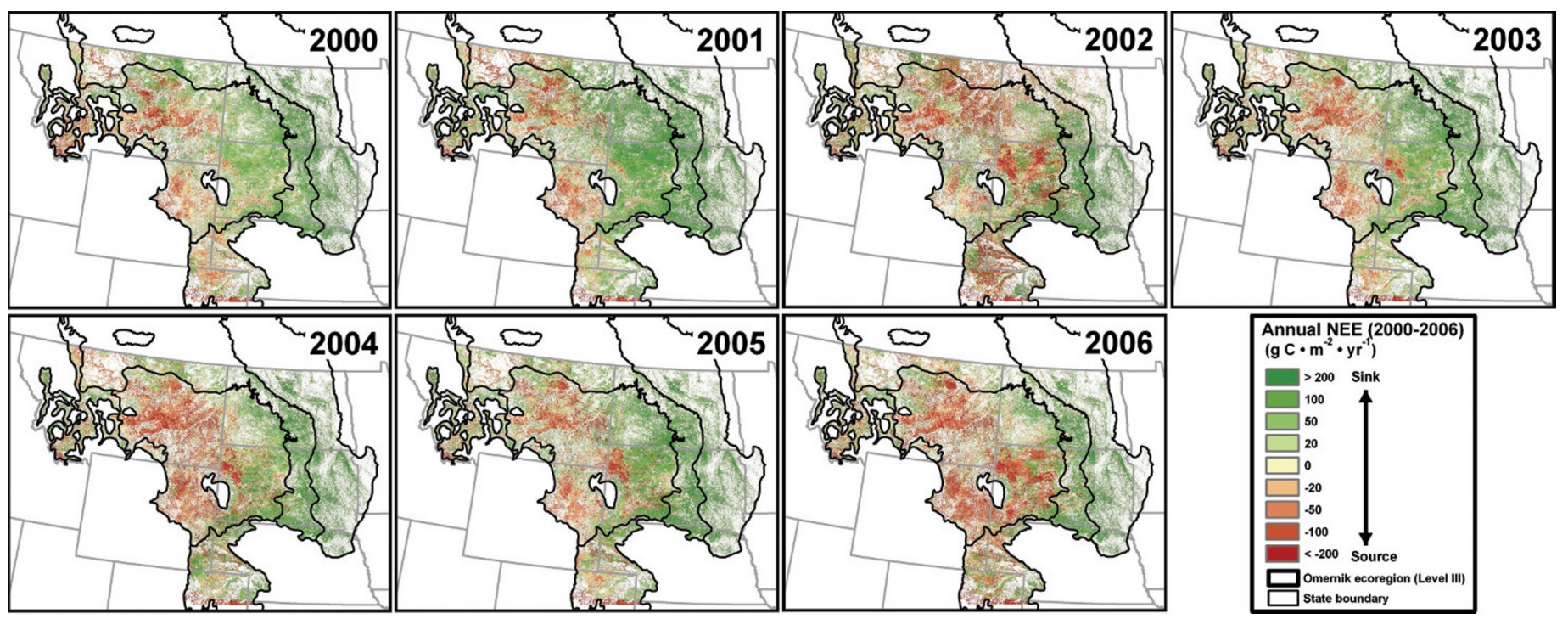

Figure 5. Maps of annual net ecosystem exchange (NEE) in the Northern Great Plains grasslands during 2000-2006. 


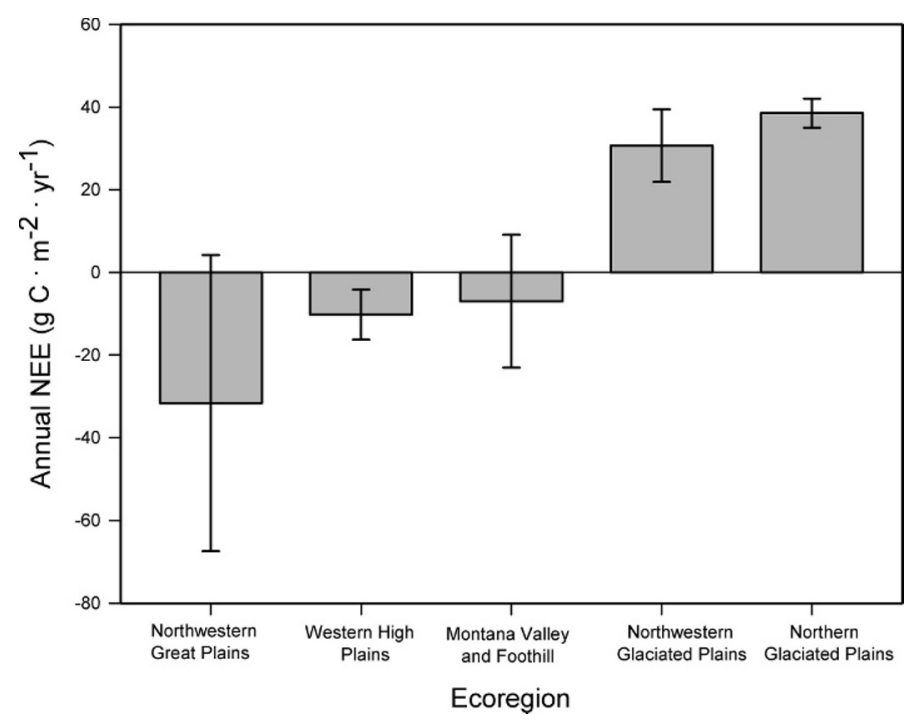

Figure 6. Average annual net ecosystem exchange (NEE) from 2000 to 2006 in five ecoregions (error bar: standard deviation of 7-yr estimated annual NEE).

\section{Drought Impact on Grassland Ecosystems}

The interannual variability of NEE in grasslands depends, to a great extent, on the amount and distribution of seasonal precipitation (Flanagan et al. 2002; Heitschmidt et al. 2005; Aires et al. 2008), especially precipitation during April and
June (Haferkamp and MacNeil 2004; Xu and Baldocchi 2004; Gilmanov et al. 2006; Ma et al. 2007). In the northern mixedgrass prairie of the Great Plains, the amounts of precipitation for April, May, and June are particularly important for grass production (Smart et al. 2005). In the study area, carbon sinks potentially occur in April-June; thus, the amount of April-June precipitation is a dominant factor in determining grassland carbon balance. The amount of precipitation received in the study area was highly variable between 2000 and 2006 . Moderate to extreme droughts were extensive across the Great Plains in 2002 and 2006 (NCDC 2009), which caused large temporal differences in NEE.

The Drought Monitor maps (http://drought.unl.edu/dm) are produced weekly for tracking and displaying the magnitude and spatial extent of drought and its impacts across the United States. The Drought Monitor map classifies drought magnitude into four levels: D1, D2, D3, and D4 (Svoboda et al. 2002). D1 indicates areas with moderate drought, which have an $11-20 \%$ probability of occurring in any given year out of $100 \mathrm{yr}$. D2 (severe drought) events occur $6-10 \%$ of the time. The probabilities of D3 (extreme) or D4 (exceptional) droughts occurring are even more remote with $3-5 \%$ and $2 \%$ or less, respectively. A fifth category, D0, designates those areas experiencing "abnormally dry" conditions, which may precede a drought or exhibit lingering impacts after a drought, and has a $21-30 \%$ probability of occurring. In our study, we calculated the mean annual percent drought-affected area defined by categories D0-D4 using the Drought Monitor maps for the

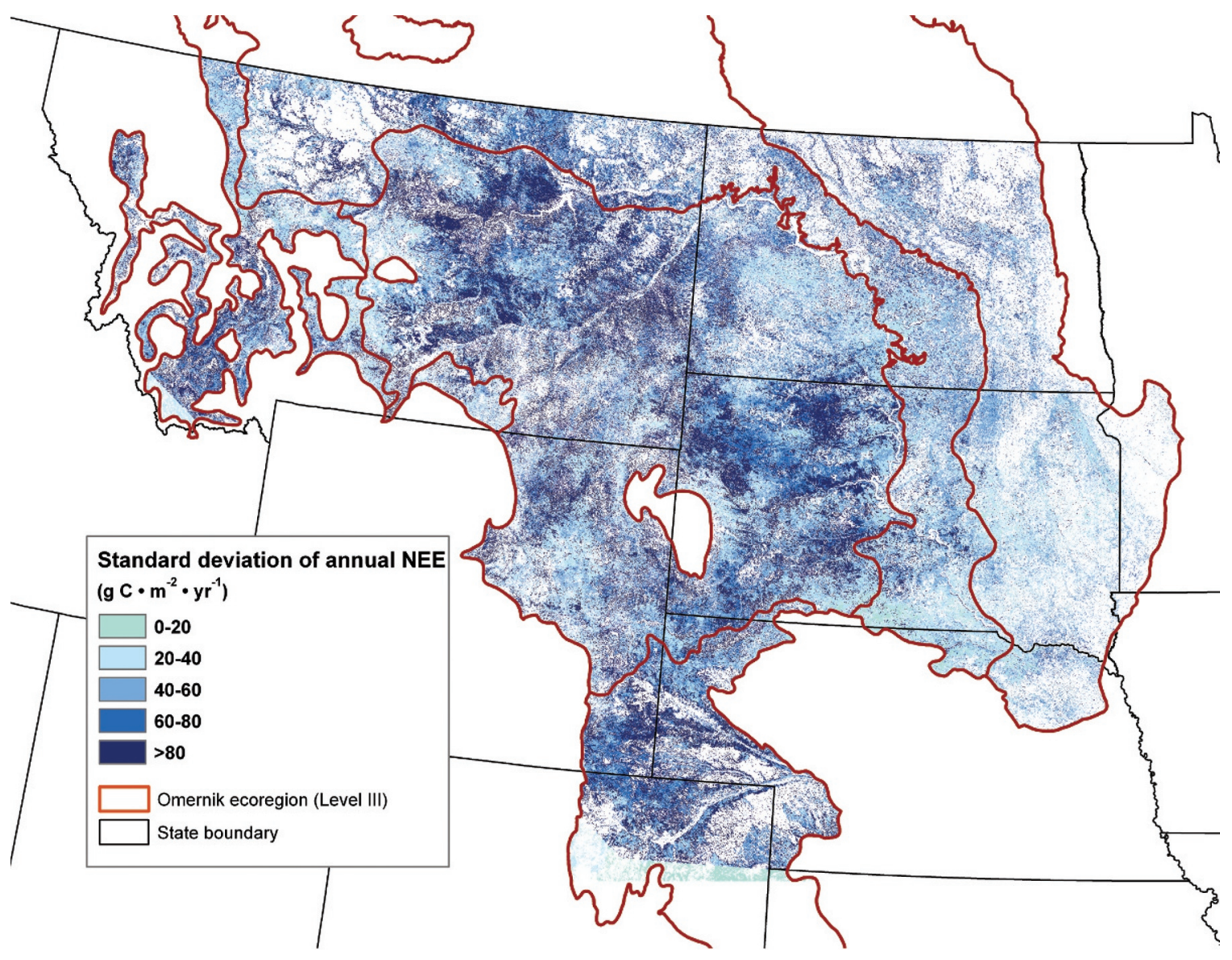

Figure 7. Map of standard deviation of annual net ecosystem exchange (NEE) from 2000 to 2006. 


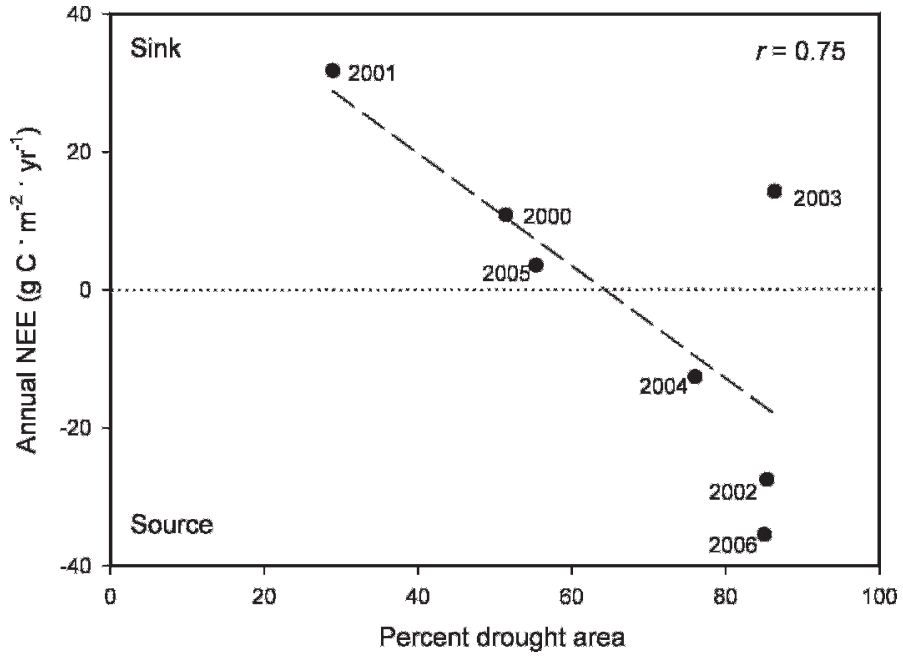

Figure 8. Correlation of piecewise regression-estimated annual net ecosystem exchange (NEE) with the percent drought-affected area over the Northern Great Plains grasslands.

High Plains. We compared the PWR-estimated annual NEE with the mean annual percent drought-affected area (Fig. 8) and found a moderately high correlation of $r=0.75$

During dry years, carbon sequestration was greatly restricted. Climatic conditions in 2002, 2004, and 2006 were characterized by extreme dryness with low April-June precipitation (Table 3). As a result, grasslands released considerable carbon to the atmosphere, and the estimated annual net carbon fluxes were $-27,-13$, and $-35 \mathrm{~g} \mathrm{C} \cdot \mathrm{m}^{-2} \cdot \mathrm{yr}^{-1}$ during the dry years of 2002, 2004, and 2006, respectively, when the AprilJune precipitation was about $36 \%, 25 \%$, and $26 \%$ below the 7-yr average, respectively. In 2003 and 2005, years following the drought years, the ecosystem switched to being a carbon sink when the region received relatively high precipitation during spring and summer.

\section{IMPLICATIONS}

We found that NEE estimated with a PWR model in the Northern Great Plains grasslands was consistently low $(-35$ to $32 \mathrm{~g} \mathrm{C} \cdot \mathrm{m}^{-2} \cdot \mathrm{yr}^{-1}$ ) and fluctuated near zero during 20002006. Although previous studies showed that the grassland ecosystem is a potential carbon sink or near equilibrium, our study showed that the Northern Great Plains grassland was a weak source for atmospheric carbon with a cumulative flux of $-15 \mathrm{~g} \mathrm{C} \cdot \mathrm{m}^{-2}$ during 2000-2006. This period included three drought-affected years. NEE exhibited large spatial variation with carbon sources in the drier west and carbon sinks in the wetter east. The Northwestern Great Plains was the largest carbon source and released carbon during 6 of the $7 \mathrm{yr}$ (except 2001) with NEE ranging from $-79 \mathrm{~g} \mathrm{C} \cdot \mathrm{m}^{-2} \cdot \mathrm{yr}^{-1}$ in 2006 to $17 \mathrm{~g} \mathrm{C} \cdot \mathrm{m}^{-2} \cdot \mathrm{yr}^{-1}$ in 2001.

Drought greatly influenced the carbon budget and can alter long-term carbon balances across Northern Great Plains grasslands, especially in the Western High Plains and Northwestern Great Plains. In our 7-yr study period with three dry years (2002, 2004, and 2006), the region was a carbon source, particularly during July and August. Precipitation during April and June was the major factor that drove the interannual variations in NEE. When April-June precipitation was reduced from $25 \%$ to $36 \%$ of the $7-y r$ average, estimated annual NEE was $-27,-13$, and $-35 \mathrm{~g} \mathrm{C} \cdot \mathrm{m}^{-2} \cdot \mathrm{yr}^{-1}$ in 2002,2004 , and 2006 , respectively. If drought severity or frequency increases in the future, the Northern Great Plains grasslands may become an even greater carbon source until a new steady state is attained. Results from our study supported our hypothesis that grassland ecosystems respond differently to various climatic conditions and that drought strongly affects the carbon balance in Northern Great Plains grasslands.

\section{ACKNOWLEDGMENTS}

We used data from the AmeriFlux and AgriFlux networks. We thank the investigators of these flux towers for providing their data. We acknowledge Gabriel Senay for providing the VegET data. We would like to thank Eugene Fosnight, Wenping Yuan, and the anonymous reviewers for their valuable comments and suggestions for revising and improving the paper.

\section{LITERATURE CITED}

Aires, L. M. I., C. A. Pio, And J. S. Pereira. 2008. Carbon dioxide exchange above a Mediterranean C3/C4 grassland during two climatologically contrasting years. Global Change Biology 14:539-555.

Arnone, J. A., III, P. S. J. Verburg, D. W. Johnson, J. D. Larsen, R. L. Jasoni, A. J. Lucchesi, C. M. Batts, C. von Nagy, W. G. Coulombe, D. E. Schorran, P. E. Buck, B. H. Braswell, J. S. Coleman, R. A. Sherry, L. L. Wallace, Y. Luo, and D. S. Schimel. 2008. Prolonged suppression of ecosystem carbon dioxide uptake after an anomalously warm year. Nature 455:383-386.

BALDOCCHI, D. D. 2003. Assessing the eddy covariance technique for evaluating carbon dioxide exchange rates of ecosystems: past, present and future. Global Change Biology 9:479-492.

Ciais, P., M. Reichstein, N. Viovy, A. Granier, J. Ogée, V. Allard, M. Aubinet, N. Buchmann, C. Bernhofer, A. Carrara, F. Chevallier, N. De Noblet, A. D. Friend, P. Friedlingstein, T. Grünwald, B. Heinesch, P. Keronen, A. Knohl, G. Krinner, D. Loustau, G. Manca, G. Matteucci, F. Miglietta, J. M. Ourcival, D. Papale, K. Pilegaard, S. Rambal, G. Seugert, J. F. Soussana, M. J. Sanz, E. D. Schulze, T. VeSALA, AND R. VAlentinI. 2005. Europe-wide reduction in primary productivity caused by the heat and drought in 2003. Nature 437:529-533.

Dugas, W. A., M. L. Heuer, and H. S. Mayeux. 1999. Carbon dioxide fluxes over Bermuda grass, native prairie, and sorghum. Agricultural and Forest Meteorology 93:121-139.

Flanagan, L. B., L. A. Wever, and P. J. Carlson. 2002. Seasonal and interannual variation in carbon dioxide exchange and carbon balance in a northern temperate grassland. Global Change Biology 8:599-615.

Frank, A. B. 2004. Six years of $\mathrm{CO}_{2}$ flux measurements for a moderately grazed mixed-grass prairie. Environmental Management 33:S426-S431.

Frank, A. B., and W. A. Dugas. 2001. Carbon dioxide fluxes over a northern semiarid, mixed-grass prairie. Agricultural and Forest Meteorology 108:317-326.

Gilmanov, T. G., L. Aires, L. Belelli, Z. Barcza, V. S. Baron, J. Beringer, D. Billesbach, D. Bonal, J. Bradford, E. Ceschia, D. Cook, C. Corradi, A. Frank, D. Gianelle, C. Gimeno, T. Gruenwald, H. Guo, N. Hanan, L. Haszpra, J. Hellman, A. Jacobs, D. A. Johnson, G. Kiely, S. Li, V. Magliulo, E. Moors, Z. Nagy, M. Nasyrov, C. Owensby, K. Pinter, C. Pio, M. Reichstein, M. J. Sanz, R. Scott, J.-F. Soussana, T. Svejcar, Z. Tuba, and G. Zhou. 2010. Productivity, respiration, and lightresponse parameters of world grassland and agro-ecosystems derived from flux-tower measurements. Rangeland Ecology and Management 63: $16-39$.

Gilmanov, T. G., J. F. Soussana, L. Aires, V. Allard, C. Ammann, M. Balzarolo, Z. Barcza, C. Bernhofer, C. L. Campbell, A. Cernusca, A. Cescatti, J. Cllfton- 
Brown, B. 0. M. Dirks, S. Dore, W. Eugster, J. Fuhrer, C. Gimeno, T. Gruenwald, L. Haszpra, A. Hensen, A. Ibrom, A. F. G. Jacobs, M. B. Jones, G. Lanigan, T. Laurila, A. Lohila, G. Manca, B. Marcolla, Z. Nagy, K. Pilegaard, K. Pinter, C. Pio, A. Raschi, N. Rogiers, M. J. Sanz, P. Stefani, M. Sutton, Z. Tuba, R. ValentinI, M. L. Williams, and G. Wohlfahrt. 2007. Partitioning European grassland net ecosystem $\mathrm{CO}_{2}$ exchange into gross primary productivity and ecosystem respiration using light response function analysis. Agriculture Ecosystems and Environment 121:93-120.

Gilmanov, T. G., T. J. Svejcar, D. A. Johnson, R. F. Angell, N. Z. Saliendra, and B. K. WYLIE. 2006. Long-term dynamics of production, respiration, and net $\mathrm{CO}_{2}$ exchange in two sagebrush-steppe ecosystems. Rangeland Ecology \& Management 59:585-599.

Gilmanov, T. G., L. L. Tieszen, B. K. Wylie, L. B. Flanagan, A. B. Frank, M. R. Haferkamap, T. P. Meyers, and J. A. Morgan. 2005. Integration of $\mathrm{CO}_{2}$ flux and remotely sensed data for primary production and ecosystem respiration analyses in the Northern Great Plains: potential for quantitative spatial extrapolation. Global Ecology and Biogeography 14:271-292.

Gilmanov, T. G., S. B. Verma, P. L. Sims, T. P. Meyers, J. A. Bradford, G. G. Burba, AND A. E. SuYker. 2003. Gross primary production and light response parameters of four Southern Plains ecosystems estimated using long-term $\mathrm{CO}_{2}$ flux tower measurements. Global Biogeochemical Cycles 17:1071. doi: 10.1029/2002GB002023.

Granier, A., M. Reichstein, N. Bréda, I. A. Janssens, E. Falge, P. Cials, T. Grünwald, M. Aubinet, P. Berbigier, C. Bernhofer, N. Buchmann, O. Facini, G. Grassi, B. Heinesch, H. Ilvesniemi, P. Keronen, A. Knohl, B. Köstner, F. Lagergren, A. Lindroth, B. Longdoz, D. Loustau, J. Mateus, L. Montagnani, C. Nys, E. Moors, D. Papale, M. Peiffer, K. Pilegaard, G. Pita, J. Pumpanen, S. Rambal, C. Rebmann, A. Rodrigues, G. Seufert, J. Tenhunen, T. Vesala, and Q. Wang. 2007. Evidence for soil water control on carbon and water dynamics in European forests during the extremely dry year: 2003. Agricultural and Forest Meteorology 143:123-145.

Haferkamp, M. R., And M. D. MacNell. 2004. Grazing effects on carbon dynamics in the northern mixed-grass prairie. Environmental Management 33, doi: 10.1007/s 00267-003-9154-X.

Hassan, Q. K., C. P.-A. Bourque, and F.-R. Meng. 2006. Estimation of daytime net ecosystem $\mathrm{CO}_{2}$ exchange over balsam fir forests in eastern Canada: combining averaged tower-based flux measurements with remotely sensed MODIS data. Canadian Journal of Remote Sensing 32:405-416.

Heitschmidt, R. K., K. D. Klement, and M. R. Haferkamp. 2005. Interactive effects of drought and grazing on Northern Great Plains rangelands. Rangeland Ecology \& Management 58:11-19.

Homer, C., C. Huang, L. Yang, B. Wylie, and M. Coan. 2004. Development of a 2001 National Land-Cover Database for the United States. Photogrammetric Engineering \& Remote Sensing 70:829-840.

Janssens, I. A., A. Freibauer, P. Cials, P. Smith, G. Nabuurs, G. Folberth, B. Schlamadinger, R. W. A. Hutjes, R. Ceulemans, E.-D. Schulze, R. Valentini, And A. J. Dolman. 2003. Europe's terrestrial biosphere absorbs 7 to $12 \%$ of European anthropogenic $\mathrm{CO}_{2}$ emissions. Science 300:1538-1542.

Joyce, L. A., D. OJima, G. A. Seielstad, R. Harriss, and J. Lackett. 2001. Potential consequences of climate variability and change for the Great Plains. In: National Assessment Synthesis Team [EDS.]. Climate change impacts on the United States: the potential consequences of climate variability and change. Report for the US Global Change Research Program. Cambridge, United Kingdom: Cambridge University Press. p. 191-217.

Kim, J., S. B. Verma, and R. J. Clement. 1992. Carbon dioxide budget in a temperate grassland ecosystem. Journal of Geophysical Research 97:6057-6063.

Li, S.- G., J. Asanuma, W. Eugster, A. Kotani, J.-J. Liu, T. Urano, T. Oikawa, G. Davaa, D. Oyunbatar, and M. Sugita. 2005. Net ecosystem carbon dioxide exchange over grazed steppe in central Mongolia. Global Change Biology 11:1941-1955.

MA, S., D. D. BALDoCCHI, L. XU, AND T. HeHN. 2007. Inter-annual variability in carbon dioxide exchange of an oak/grass savanna and open grassland in California. Agricultural and Forest Meteorology 147:157-171.

Meyers, T. P. 2001. A comparison of summertime water and $\mathrm{CO}_{2}$ fluxes over rangeland for well watered and drought conditions. Agricultural and Forest Meteorology 106:205-214.
Morgan, J. A., J. D. Derner, D. G. Milchunas, and E. Pendall. 2008. Management implications of global change for Great Plains rangelands. Rangelands $30: 18-22$.

Nagy, Z., K. Pintér, S. Czóbel, J. Balogh, L. Horváth, S. Fóti, Z. Barcza, T. Weidinfer, Z. Csintalan, N. Q. Dinh, B. Grosz, and Z. Tuba. 2007. The carbon budget of semi-arid grassland in a wet and a dry year in Hungary. Agriculture Ecosystems and Environment 121:21-29.

[NCDC] National Climatic Data Center. 2009. Annual State of the Climate Report. Available at: http://www.ncdc.noaa.gov/oa/climate/research/state-of-climate. Accessed 16 October 2009.

Oechel, W. C., G. L. Vourlitis, S. J. Hastings, R. C. Zulueta, L. Hinzman, and D. Kane. 2000. Acclimation of ecosystem $\mathrm{CO}_{2}$ exchange in the Alaskan Arctic in response to decadal climate warming. Nature 406:978-981.

OMERNIK, J. M. 1987. Map supplements: ecoregions of the conterminous United States. Annals of the Association of American Geographers 77:118-125.

Pereira, J. S., J. A. Mateus, L. M. Aires, G. Pita, C. Pio, J. S. David, V. Andrase, J. Banza, T. S. David, T. A. Paco, and A. Rodrigues. 2007. Net ecosystem carbon exchange in three contrasting Mediterranean ecosystems-the effect of drought. Biogeosciences 4:791-802.

PhiLlips, R. L., AND O. BeERI. 2008. Scaling-up knowledge of growing-season net ecosystem exchange for long-term assessment of North Dakota grasslands under the Conservation Reserve Program. Global Change Biology 14:1-10.

Piad, S., J. Fang, L. Zhou, K. Tan, and S. Tao. 2007. Changes in biomass carbon stocks in China's grasslands between 1982 and 1999. Global Biogeochemical Cycles 21:GB2002. doi:10.1029/2005GB002634.

QuinLAN, J. R. 1993. C4.5: programs for machine learning. San Francisco, CA, USA: Morgan Kaufmann Publishers. 302 p.

ReEd, B. C. 2006. Trend analysis of time-series phenology of North America derived from satellite data. GIScience \& Remote Sensing 43:1-15.

Reed, B. C., J. F. Brown, D. Vanderzee, T. R. Loveland, J. W. Merchant, and D. O. OHLEN. 1994. Measuring phenological variability from satellite imagery. Journal of Vegetation Science 5:703-714.

Senay, G. B. 2008. Modeling landscape evapotranspiration by integrating land surface phenology and a water balance algorithm. Algorithms 1:52-68.

Sims, P. L., And J. A. Bradford. 2001. Carbon dioxide fluxes in a Southern Plains prairie. Agricultural and Forest Meteorology 109:117-134.

Smart, A. J., B. Dunn, and R. Gates. 2005. Historical weather patterns: a guide for drought planning. Rangelands 27:10-12.

Suyker, A. E., S. B. Verma, AND G. G. BuRBA. 2003. Interannual variability in net $\mathrm{CO}_{2}$ exchange of a native tallgrass prairie. Global Change Biology 9:1-11.

Svejcar, T., R. Angell, J. A. Bradford, W. Dugas, W. Emmerich, A. B. Frank, T. Gilmanov, M. Haferkamp, D. A. Johnson, H. Mayeux, P. Mielnick, J. Morgan, N. Z. Saliendra, G. E. Schuman, P. L. Sims, and K. Snyder. 2008. Carbon fluxes on North American rangelands. Rangeland Ecology \& Management 61:465-474.

Svoboda, M., D. Lecomte, M. Hayes, R. Heim, K. Gleason, J. Angel, B. Rippey, R. Tinker, M. Palecki, D. Stooksbury, D. Miskus, and S. Stevens. 2002. An introduction to the Drought Monitor. Bulletin of the American Meteorological Society 83:1181-1190.

Tieszen, L. L., B. C. Reed, N. B. Bliss, B. K. Wylie, and D. D. Donovan. 1997. NDVI, C 3 and $\mathrm{C}_{4}$ production, and distributions in Great Plains grassland land cover classes. Ecological Applications 7:59-78.

Turner, D. P., W. D. Ritts, W. B. Cohen, S. T. Gower, M. Zhao, S. W. Running, S. C. Wofsy, S. Urbanski, A. L. Dunn, and J. W. Munger. 2003. Scaling gross primary production (GPP) over boreal and deciduous forest landscapes in support of MODIS GPP product validation. Remote Sensing of Environment 88:256-270.

World Resources Institute. 2000. Taking stock of ecosystems-grassland ecosystems. In: World resources 2000-2001: people and ecosystems: the fraying web of life. Washington, DC, USA: World Resources Institute. p. 119-131.

Wylie, B. K., E. A. Fosnight, T. G. Gilmanov, A. B. Frank, J. A. Morgan, M. R. Haferkamp, and T. P. Meyers. 2007. Adaptive data-driven models for estimating carbon fluxes in the Northern Great Plains. Remote Sensing of Environment 106:399-413.

Wylie, B. K., T. G. Gilmanov, D. A. Johnson, N. Z. Saliendra, K. Akshalov, L. L. Tieszen, AND B. C. ReEd. 2004. Intra-seasonal mapping of $\mathrm{CO}_{2}$ flux in rangelands of 
northern Kazakhstan at one-kilometer resolution. Environmental Management 33:S482-S491.

Xiao, J., Q. Zhuang, D. D. Baldocchi, B. E. Law, A. D. Richardson, J. Chen, R. Oren, G. Starr, A. Noormets, S. Ma, S. B. Verma, S. Wharton, S. C. Wofsy, P. V. Bolstad, S. P. Burns, D. R. Cook, P. S. Curtis, B. G. Drake, M. Falk, M. L. Fischer, D. R. Foster, L. Gu, J. L. Hadley, D. Y. Hollinger, G. G. Katul, M. Litvak, T. A. Martin, R. Matamala, S. McNulty, T. P. Meyers, R. K. Monson, J. W. Munger, W. C. Oechel, K. Tha Paw U, H. P. Schmid, R. L. Scott, G. Sun, A. E. Suyker, and M. S. ToRn. 2008. Estimation of net ecosystem carbon exchange for the conterminous United States by combining MODIS and AmeriFlux data. Agricultural and Forest Meteorology 148, doi:10.1016/j.agrformet.2008. 06.015 .
Xu, L., AND D. D. BALDocCHI. 2004. Seasonal variation in carbon dioxide exchange over a Mediterranean annual grassland in California. Agricultural and Forest Meteorology 123:79-96.

Yang, F., K. Ichil, M. A. White, H. Hashimoto, A. R. Michaelis, P. Votava, A. Zhu, A. Huete, S. W. Running, and R. R. Nemani. 2007. Developing a continental-scale measure of gross primary production by combining MODIS and AmeriFlux data through Support Vector Machine approach. Remote Sensing of Environment 110:109-122.

Zhang, L., B. K. Wylie, T. Loveland, E. A. Fosnight, L. L. Tieszen, and L. J. 2007. Evaluation and comparison of gross primary production estimates for the Northern Great Plains grasslands. Remote Sensing of Environment 106:173-189. 